\title{
CORPORATE GOVERNANCE RULES IN THE FUNCTION OF LONG TERM SAFETY OF INSURER
}

\author{
Ivona Vrdoljak Raguž ${ }^{1}$, Dejan Drljača ${ }^{2}$, Lidija Barjaktarović ${ }^{3}$ \\ ${ }^{1}$ University of Dubrovnik, Department of Economics and Business Economics, Dubrovnik, Croatia \\ ${ }^{2}$ Dunav Insurance Company a.d.o., Belgrade, Serbia \\ ${ }^{3}$ Faculty of Business in Belgrade, Singidunum University, Belgrade, Serbia
}

\section{Key words:}

corporate governance,

risks,

disclosure,

public information,

insurance.

Corporate governance rules and pillars insist on improvement of risk management and internal audit within the company. Accordingly, establishment of adequate risk management is precondition for objective, reliable, comprehensive and objective reporting.

Subject of this research is to determine the level of transparency in disclosing information in insurance sector in Republic of Serbia. The aim of research it to obtain data what can be improved in the process of implementing the Third Pillar of Solvency II.

This research paper was part of the research project “Advancing Serbia's Competitiveness in the Process of EU Accession”, No. 47028, during the period 20112015, financed by the Serbian Ministry of Science and Technological Development.

\section{INTRODUCTION}

Adequate insurer reaction on identifying risks, especially those estimated at high level, spreading corporate culture and applying the principles, rules and standards of corporate governance, are crucial for efficient and effective decision making of company's board.

Corporate governance represents defined structures and processes for managing and controlling legal entities [4]. OECD's frame for corporate governance is based on four values [4]: objectiveness, commitment, transparency and responsibility. Potential benefits from good corporate governance are: improved operative efficiency, obtained access to equity markets, lower price of equity, and better reputation of the company, its members of managing board and managers. Accordingly, board of insurance company should create conditions for permanent analysis of surrounding, market researches, collection of all relevant information for performing business and decision making, i.e. activities connected to risk (internal and external) identification (such as macroeconomic factors, socio-political trends, wishes and needs of insured, regulation, forecasting of future, etc.). All of those activities are in the function of execution of defined targets and strategies of insurer. Moreover, they should provide operative performance with lower exposures to risks. Finally, suitable organizational structure of insurance company, proactive approach in human resources management and level of development of internal control and financial management are guarantee for performing insurance business with defined target [3].

Project Solvency II brings a qualitatively different approach to risk management and totally new financial reporting concept. It has characteristics of corporate governance. Three pillars of Solvency II (area of implementation) are [5]: 1) quantitative requests, 2) supervisory process and 3) market discipline. Implementation of Solvency II, especially the second (risk man- agement, internal audit, ORSA - Own Risk and Solvency Assessment, supervisory) and the third (disclosure requirements and transparency) pillar provides indirect benefits for corporate governance in insurance company $[1,2,3]$.

Subject of this research is to determine the fulfilled level of disclosure requirements in Serbian insurance sector. The aim of research is to identify what can be improved in further process of implementation of Solvency II. Data base for research are information available on web sites of insurance companies and National Bank of Serbia in 2013 [7, 9].

\section{SPREADING CORPORATE CULTURE AND CORPORATE GOVERNANCE}

"Corporate culture is based on preconditions, beliefs, values and way of behaviour which employees developed and accepted as common experience. They express it through symbols, routing their behaviour and meaning in business" [4]. Spreading of corporate culture and human resource management is a precondition for successful execution of company's targets. It helps employees to understand their own tasks, role and importance in the process of achieving aims in the most adequate way. Moreover, it protects interests of all stakeholders. Finally, introduction of corporate governance will provide growth and development of the company, where interests of customers, third parties and state will not be damaged.

Insurer accepts and announced policies connected to stakeholders in order to establish adequate exchange of information. Moreover, one of expending corporate governance elements is to provide freedom to the third parties to inform about activities which are not in accordance with law, statutory acts and rules of insurance competence. Finally, insurance companies should be responsible toward insured and public for their acts if they would like to keep favourable business reputation. 
Element o Corporate

Governance (IFC)

General management

structure of

shareholder company

Assembly of shareholders, Board of company, Executive bodies, Committee of board of company; Bodies of internal supervisory; External supervisory, Secretary of company
Insurance companies in Serbia (current regulation)

Assembly of shareholders; Bodies (Management, Executive), Head of Risk Management Division; Head of Asset and Liability Management Unit; Certified Actuarial; Compliance Manager; Heads of organizational units

Founding Act; Statute of the company; AnnounceGeneral regulation ments of statutory documents and right to access of the company to those documents; Codex of corporate governance of the company; Ethic codex of the company;

General statutory documents prescribed by Law on Legal Entities, Law on Insurance and other connected state's decisions

Forming and responsibilities of the board; Way of Board of the recruiting and firing; Committee bodies; Working company procedures of the board; Duties and responsibilities of board members; Evaluation; Salaries and fees;

Executive bodies and their responsibilities; Structure, nomination and fire; Working procedures Executive bodies for executive bodies; Working procedures of the board; Duties and responsibilities of board members; Evaluation; Salaries and fees;
Equity influence on corporate governance

General terms connected to initial equity; increase of the equity; protection of equity; obligatory and statutory reserves
Qualifications and competences of board members are defined by Law on Insurance and Decisions on Internal Controls and Audits

Qualifications and competences of board members are defined by Law on Insurance and Decisions on Internal Controls and Audits

Externally: National Bank of Serbia, Law on Equity Market; Law on Legal Entities. Internally: Risk Management Department; Asset and Liability Management Department within Finance Division; Certified Actuarial; Internal Auditor

Importance of corporate transaction

High value of assets - way of getting and using; Acquiring control equity - participation; Legal acts where exist personal interest

It is defined by Law on Legal Entities, Law on Insurance, Law on Equity Market

Definition, principles, announcement vs. transparency; business secret and inside information; obligatory public information (financial and business results, targets, control packet ownership and Information voice right, information about board members, transparency employees and other risk owners of the business; Law on Legal Entities, Law on Equity Markets and National Bank of Serbia (regulates and controls it). report on corporate governance; voluntary announcement (internet sites of societies; means of public reporting);

Internal audit bodies; Commission for auditing; Business of internal auditing; System of internal controls in comparable practice; Auditing Commission;
Activates are regulated by Law on Auditing, Law on Insurance, International Frame for Professional Practice; Plan, Programme and Instruction for Operative Work of Internal Audit.
Acts of supervisory and auditing

Table 1: Parallel review of accepted and implemented elements of corporate governance in insurance companies in Serbia

[Source: created by the authors based on the available data in references 1, 2, 3, 4, 5, 7 and 8]

Employees should get all necessary help in the process of understanding procedures, rules and importance of internal audit in achievement of company's targets. It is provided by permanent improvement of corporate governance system. Moreover, activities connected to support in providing ethical standard and principles in taking responsibilities regarding activities which will be taken or taken are crucial for establishing adequate corporate governance system. Generally speaking, human resources are very important risk. Elements and factors which have elements on this risk are requirement, training of employees and their motivation for work, way of delegating right, commitments, responsibilities and capabilities of the company to keep the most competent employees and managers. Accordingly, principles of ethic responsibility of all employees should be in the function of company's interest and progress, especially in favour of insured. Finally, introduction of system of internal audit guarantees performance of insurer in accordance with ethic codex and principles of ethic responsibility.

\section{DISCLOSURE REQUIREMENTS}

Insurance companies are doing business in accordance with international principles of corporate governance, which means that hey announced relevant information and data. However, insurer takes care not to ruin own competitiveness position on insurance market.

Insurers are obliged to announce financial reports prepared in accordance with ISAR, their targets in future period, policies which company applies in business, relevant visible risks to whom insurer is exposed or will be, control pocket ownership and right voice, as well as possible changes in ownership structure. However, there is information which is not transparent in insurers' business, such as information about policies and practices in recruiting board members and key staff, their qualification, process of recruitment, their participation in business of other companies which perform business in the country and abroad, which criteria were applied in hiring independent board 


\begin{tabular}{|c|c|c|}
\hline Type of information & $\begin{array}{l}\text { Announce- } \\
\text { ment }\end{array}$ & Comment \\
\hline $\begin{array}{l}\text { Business activities } \\
\text { Basic data about insurer } \\
\text { Targets of insurer } \\
\text { Products } \\
\text { General, special and additional } \\
\text { business terms and conditions } \\
\text { Organizational structure }\end{array}$ & $\begin{array}{l}+/- \\
+ \\
- \\
+ \\
+/- \\
+\end{array}$ & $\begin{array}{l}\text { Available data on head quarter of the company, contacts of relevant } \\
\text { intermediaries, agents, brokers, branches and organizational parts for } \\
\text { disclaim. Information about insurers' products have reasonable quality; } \\
\text { in all documents it should be clearly expressed cases when insured can } \\
\text { request compensation, how it should be done - clear procedure, who is } \\
\text { relevant body within insurance company or National Bank of Serbia. }\end{array}$ \\
\hline Financial reports & + & $\begin{array}{l}\text { Basic financial figures are synthetically expressed; more detailed infor- } \\
\text { mation and data about corrected value of receivables and investments } \\
\text { should be added. }\end{array}$ \\
\hline Parts of accounting policies & $+/-$ & $\begin{array}{l}\text { Insurers prepare official yearly reports in accordance with International } \\
\text { Standards of Accounting Reporting (IARS), especially ISAR } 4 \text { and ISAR } \\
\text { 7. It is mention in the part of expressing basic categories of insurers' core } \\
\text { business. }\end{array}$ \\
\hline External auditing report & + & Announced in total. \\
\hline Opinion of certified actuarial & $+/-$ & $\begin{array}{l}\text { Opinion is expressed in two paragraphs in yearly report (only part); } \\
\text { quarterly actuarial reports are not available. }\end{array}$ \\
\hline $\begin{array}{l}\text { Control packet ownership and } \\
\text { right voice }\end{array}$ & + & Ownership equity structure is expressed as synthetic figure. \\
\hline $\begin{array}{l}\text { Information about managing and } \\
\text { executive Board members }\end{array}$ & $+/-$ & $\begin{array}{l}\text { Available info on name and surname; in majority number without CV; } \\
\text { there is more relevant data which are not expressed on transparent way. }\end{array}$ \\
\hline $\begin{array}{l}\text { Information about policies and } \\
\text { practice in recruiting members of } \\
\text { executive board }\end{array}$ & - & $\begin{array}{l}\text { There is no transparent data about policies and practices of recruiting } \\
\text { board, their fees and benefits, terms for firing board members and key } \\
\text { staff, their qualification... }\end{array}$ \\
\hline $\begin{array}{l}\text { Visible risk factors with material } \\
\text { influence }\end{array}$ & $+/-$ & $\begin{array}{l}\text { Risk and equity management is available in yearly report, and it is in ac- } \\
\text { cordance with ISAR } 7 \text {. It means that synthetic information can be found } \\
\text { about credit and market (FX risk, interest rate risk and risk of fluctuation } \\
\text { of financial instruments) risks; results of run-off tests for provisioned re- } \\
\text { serves, VaR analysis of market risks in investment portfolio. It is explic- } \\
\text { itly mentioned that those information is took from Risk Management } \\
\text { Report of Insurer for particular year (which is not in appendix). }\end{array}$ \\
\hline Transaction on connected entities & - & $\begin{array}{l}\text { Especially in the case of transactions which were executed on non-mar- } \\
\text { ket conditions. }\end{array}$ \\
\hline
\end{tabular}

Table 2: Business information and data which should be announced by insurer in Republic of Serbia

[Source: created by the authors based on the available data in reference 9]

members, possible conflict of interest between board members, general manager and other heads (especially with persons who are in charge of independent functions, such as internal audit, actuarial, risk and compliance managers), in order to provide truth information to shareholder. Insurers should disclose in their annual risk management reports data on inadequate Asset and Liability Management, covering especially insurance risk, market risk, risk of term and structural imbalances of assets and liabilities, investment risk, operational risk (including strategic risk), legal and reputational risk. Moreover, insurers should provide transparency in announcing data connected to investment risk and success in doing business, especially data about investment targets, investment policies, investment management, and term and structural balance of assets and liabilities.

International Accounting Standards and International Standards of Accounting Reporting improved practice of Serbian insurance companies, such as information on development of collection per premium, development of damages, discrepancies between real and expected damages, basis for calculating return on investment, estimated time and value of net cash income and outcome, sensitivity of financial result and equity on movements in risk factors. However, Solvency II rules introduced huge qualitative changes i.e. disclosure requirements in terms of volume and quality.

\section{CONCLUSIONS}

Research results confirmed that Serbian insurers have formally fulfilled disclosure requirements, but they should improve quality of core information for all stakeholders. Serbian insurers should improve corporate governance and practice of announcing rules of corporate governance, especially information connected to business policies, strategies, transactions with controlled entities, criteria and practice for hiring board members, their fees and bonuses, and investment policies.

Key point which should be further improved in accordance with the third pillar of Solvency II are acceptance of the additional commitments in the case when test of provision and premium satisfaction indicate these have been underestimated, and the method of calculation solvency capital requirement. 


\section{REFERENCES}

[1] Drljača, D., „Building internal control system and causes of insolvency of insurance companies", Risk measurement and control in insurance, Publisher University of Belgrade, Faculty of Economics Publishing Centre, Belgrade, Serbia, 2014, p. 271-292.

[2] Drljača, D., „Strukturno usklađivanje aktive i pasive u svetlu zahteva projekta Solventnost II“, Nadzor i kontrola poslovanja osiguravajućih Kompanija, Ekonomski Fakultet Univerziteta u Beogradu, Beograd, Maj 2011., str. 308-327.

[3] Drljača, D., Upravljačko računovdstvo kao okvir i instrument upravljanja rizicima aktive i pasive u društvima za osiguranje, Centar za kulturu, Mladenovac, 2011, str. 1-448.

[4] International Financial Corporation (IFC), Corporate Governance - Handbook, Belgrade, 2011.
[5] Pak, J., Jeremić, Lj. Barjaktarović, L., Osnovi osiguranja, Univerzitet Singidunum, Beograd, str. 234-246.

[6] Politike upravljanja rizicima u Kompaniji "Dunav osiguranje" a.d.o., Beograd, 21.01.2013., Sl. list 3/13, D01-423-PO-04

[7] Web site of NBS (2014) Insurance Supervision (access on: 09/22/14), [available on http://www.nbs.rs /internet/cirilica/60/60_6/index.html]

[8] Web site of NBS (2014) Insurance Supervision Directives (access on: 09/22/14), [available on http://www.nbs.rs/ export/sites/default/internet/latinica/20/osg/smernica_2_ korp_upravljanje.pdf]

[9] Web sites of Serbian insurance companies (2014) Insurance Market Participants (access on: 09/22/14), [available on http://www.nbs.rs/internet/cirilica/60/60_1/index.html]

\section{PRAVILA KORPORATIVNOG UPRAVLJANJA U FUNKCIJI DUGOROČNE SIGURNOSTI OSIGURAVAČA}

Ivona Vrdoljak Raguž1, Dejan Drljača², Lidija Barjaktarovićs

${ }^{1}$ Sveučilište u Dubrovniku, Odjel za ekonomiju i poslovnu ekonomiju, Lapadska obala 7, Dubrovnik, Hrvatska, ivona.vrdoljak@unidu.hr

${ }^{2}$ Kompanija Dunav osiguranje, Makedonska 4, Beograd, Srbija, dejan.drljaca@dunav.com

${ }^{3}$ Poslovni fakultet u Beogradu, Univerzitet Singidunum, Danijelova 32, Beograd, Srbija, lbarjaktarovic@singidunum.ac.rs

\section{Apstrakt:}

Širenje korporativne kulture i prihvatanje pravila i principa korporativnog upravljanja su osnovne pretpostavke za obavljanje delatnosti osiguravača u skladu sa standardima savremenog tržišnog privređivanja i obezbeđivanja adekvatnog tržišnog nastupa. Konačno, pravila korporativnog upravljanja predstavljaju svojevrsnu garanciju transparentnosti u postupku obelodanjivanja informacija i smanjenja rizika u poslovanju osiguravača.

Pravila i principi na kojima se temelje politike korporativnog upravljanja, nedvosmisleno insistiraju na unapređenju procesa upravljanja rizicima i sistema internih kontrola. Zbog toga organizacija i uspostavljanje sistema upravljanja rizicima u budućnosti mora biti jedan od prioriteta i ujedno uslov za objektivno, pouzdano, sveobuhvatno i istinito izveštavanje.

Predmet ovog rada je utvrđivanje nivoa transparentnosti u obelodanjivanju (objavljivanju) podataka u sektoru osiguranja Republike Srbije. Cilj rada je da ukaže šta bi moglo da se unapredi u procesu dalje primene trećeg stuba Solventnosti II.

\section{Ključne reči:}

korporativno upravljanje, rizici, obelodanjivanje, osiguranje. 